

\section{Laboratory Test Report for ThermaStor Ultra-Aire XT150H Dehumidifier}

\section{Dane Christensen and Jon Winkler}

Prepared under Task No. BET98001

Technical Report NREL/TP-550-47215

December 2009

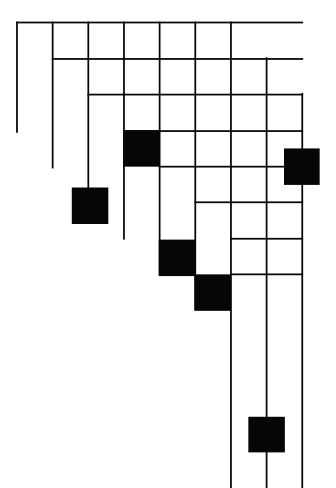




\section{NOTICE}

This report was prepared as an account of work sponsored by an agency of the United States government. Neither the United States government nor any agency thereof, nor any of their employees, makes any warranty, express or implied, or assumes any legal liability or responsibility for the accuracy, completeness, or usefulness of any information, apparatus, product, or process disclosed, or represents that its use would not infringe privately owned rights. Reference herein to any specific commercial product, process, or service by trade name, trademark, manufacturer, or otherwise does not necessarily constitute or imply its endorsement, recommendation, or favoring by the United States government or any agency thereof. The views and opinions of authors expressed herein do not necessarily state or reflect those of the United States government or any agency thereof.

Available electronically at http://www.osti.gov/bridge

Available for a processing fee to U.S. Department of Energy and its contractors, in paper, from:

U.S. Department of Energy

Office of Scientific and Technical Information

P.O. Box 62

Oak Ridge, TN 37831-0062

phone: 865.576 .8401

fax: 865.576 .5728

email: mailto:reports@adonis.osti.gov

Available for sale to the public, in paper, from:

U.S. Department of Commerce

National Technical Information Service

5285 Port Royal Road

Springfield, VA 22161

phone: 800.553.6847

fax: 703.605.6900

email: orders@ntis.fedworld.gov

online ordering: http://www.ntis.gov/ordering.htm 


\section{Abstract}

This report documents the measured performance of the ThermaStor Ultra-Aire XT150H Dehumidifier. The equipment is an ENERGY STAR ${ }^{\circledR}$ vapor-compression cycle wholehouse unit. Its performance was measured across a wide range of inlet air conditions and fit to a numerical model with R-squared values greater than 0.998 for electrical power consumption, sensible and latent load removal. The numerical fit was then used to implement the Zone Air Direct-Expansion (DX) Dehumidifier performance model in EnergyPlus.

The authors would like to acknowledge Jeff Tomerlin of NREL for his assistance with data collection. 


\section{Acronyms}

AHAM American Home Appliance Manufacturers

ANSI American National Standards Institute

CFM cubic feet per minute

DB dry bulb

DX direct expansion

HVAC heating, ventilating, and air conditioning

RH relative humidity

SCFM standard cubic feet per minute 


\section{Contents}

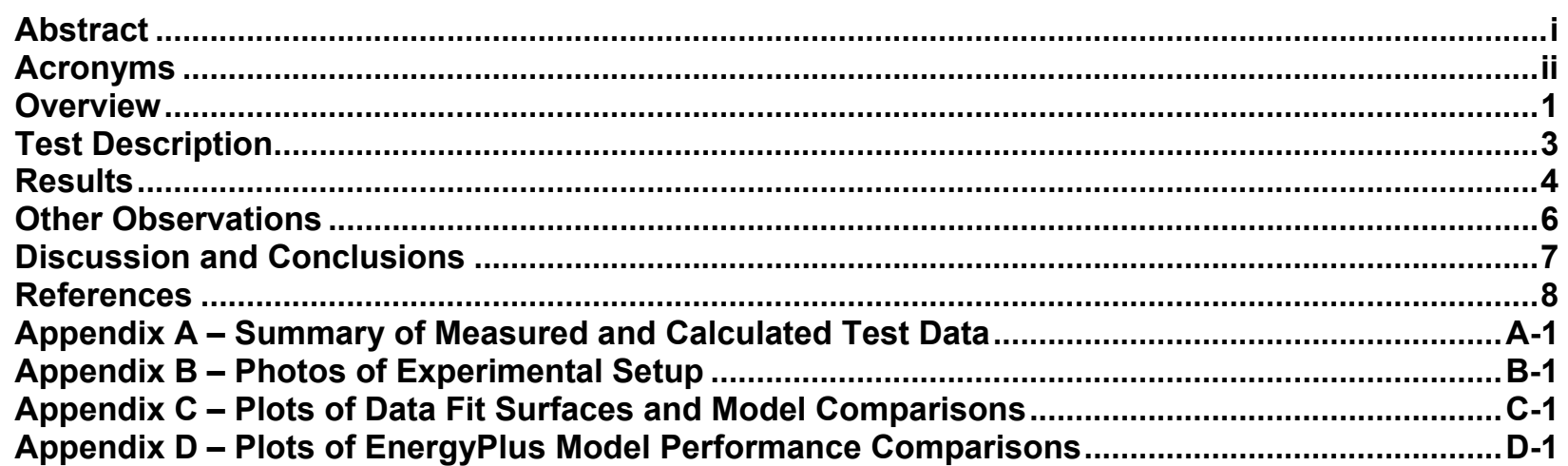

\section{Figures}

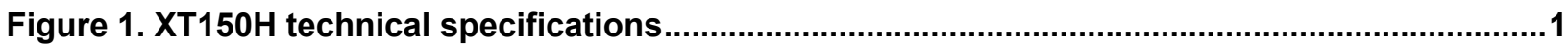

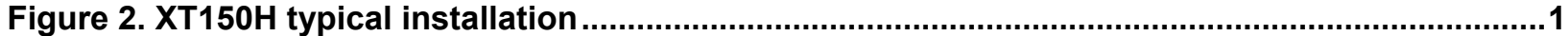

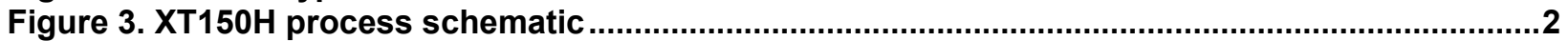

Figure 4. Psychrometric chart showing test points ......................................................................

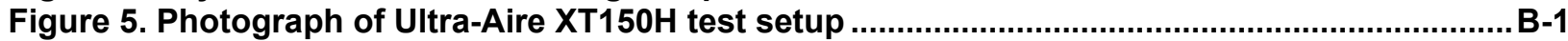

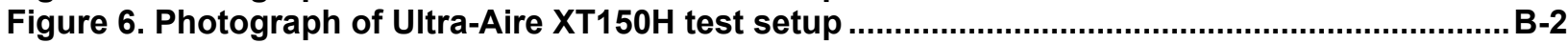

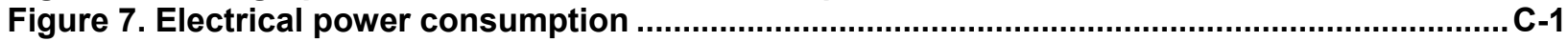

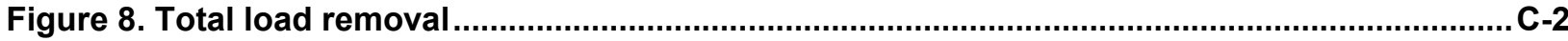

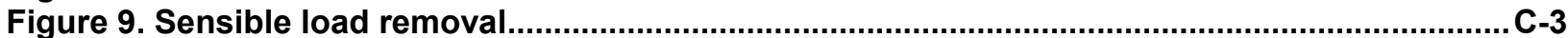

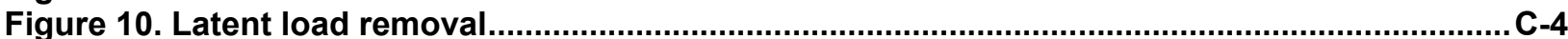

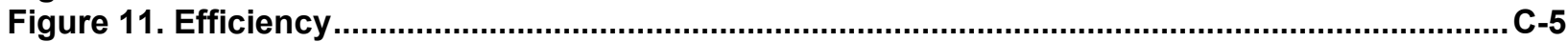

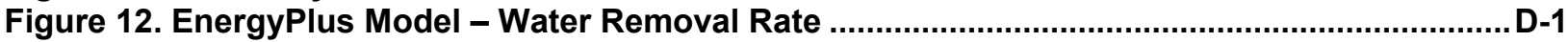

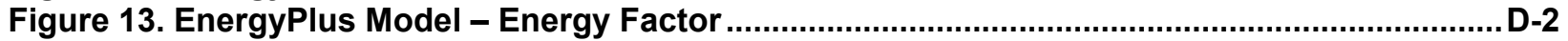

\section{Tables}

Table 1. Summary of Measured Parameter Balances ........................................................................

Table 2. Curve Fit Coefficients and Coefficient of Determination for Measured Effects of the Ultra-Aire XT150H Dehumidifier

able 3: Curve Fit Coefficients and Coefficient of Determination for EnergyPlus

Performance Curves for the Ultra-Aire XT150H Dehumidifier......................................................5

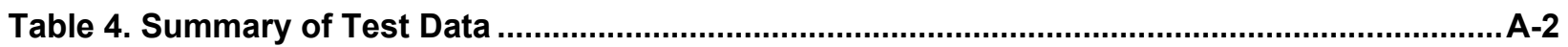

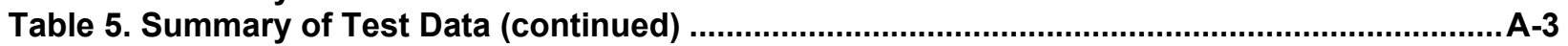




\section{Overview}

The ThermaStor Ultra-Aire XT150H Dehumidifier is designed as an efficient vapor-compression cycle whole-house unit. It can be used as a stand-alone system with unique ductwork or can be incorporated into an HVAC system. It has an outdoor air inlet for optional use in dehumidifying ventilation air. The equipment was EnergyStar rated, with the best rated performance among the residential EnergyStar dehumidifiers, at the time of testing. Manufacturer Specifications from the Owner's Manual are shown in Figure 1. A depiction from the Owner's Manual of a standard installation is shown in Figure 2. Figure 3 shows a functional schematic of the refrigerant loop, air flow and condensate removal.

\begin{tabular}{|c|c|}
\hline \multicolumn{2}{|l|}{ 2. Specifications } \\
\hline Model: & $\begin{array}{l}\text { Ultra-Aire XT150H } \\
\text { Indoor Air Quality System }\end{array}$ \\
\hline Electrical: & $\begin{array}{l}110-120 \mathrm{VAC}, 6.9 \mathrm{Amps}, 60 \mathrm{~Hz} \text {, } \\
\text { grounded }\end{array}$ \\
\hline Water Removal Capacity: & 150 pints/day @ 80 ${ }^{\circ}, 60 \%$ RH \\
\hline Operating Temp. Range: & $56^{\circ} \mathrm{F}$ min., $100^{\circ} \mathrm{F}$ max. \\
\hline \multirow[t]{2}{*}{ Air Flow: } & 415 CFM @ 0.0" WG \\
\hline & $365 @ 0.4 "$ WG \\
\hline Refrigerant Charge: & $2 \mathrm{lb} ., \mathrm{R}-410 . \mathrm{A}$ \\
\hline $\begin{array}{l}\text { Duct connections: } \\
\text { (ovaled) }\end{array}$ & Round $10^{\prime \prime} \& 6$ " inlets, $10^{\prime}$ outlet \\
\hline Filter Size: & $2^{\prime \prime} \times 16^{\prime \prime} \times 16^{\prime \prime}$ \\
\hline Size (w/o duct collars): & $37 "$ wide $X 22$ " high $X 205 / 8$ " deep \\
\hline Unit Weight: & 134 lbs. \\
\hline
\end{tabular}

Figure 1. XT150H technical specifications [1]

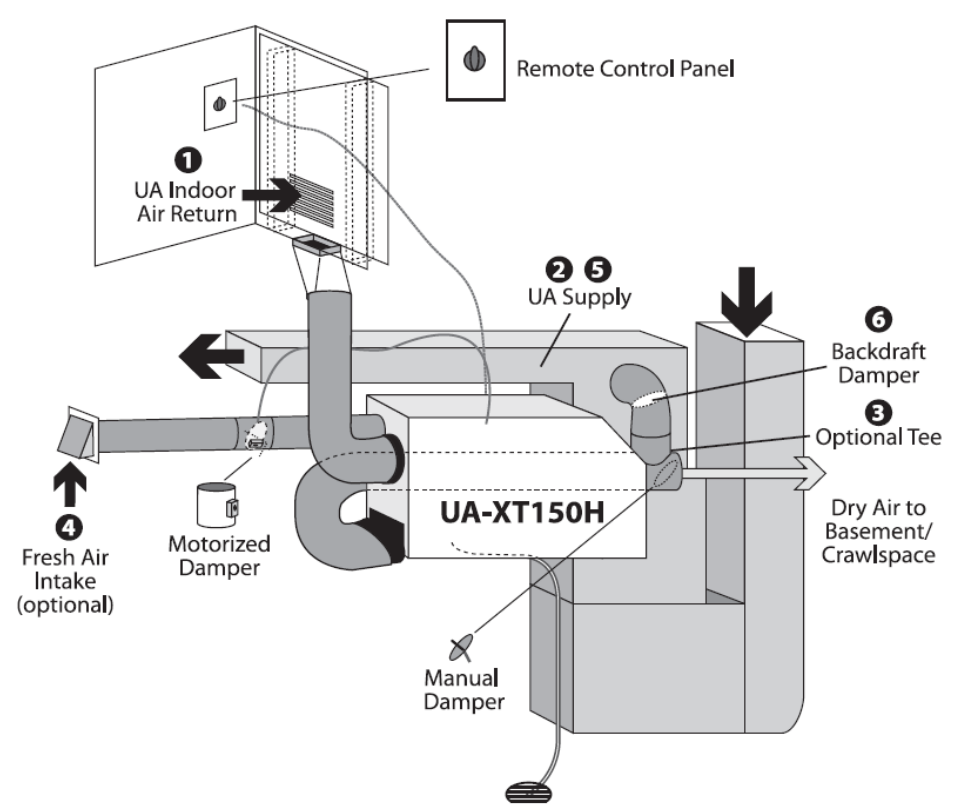

Figure 2. XT150H typical installation [1] 


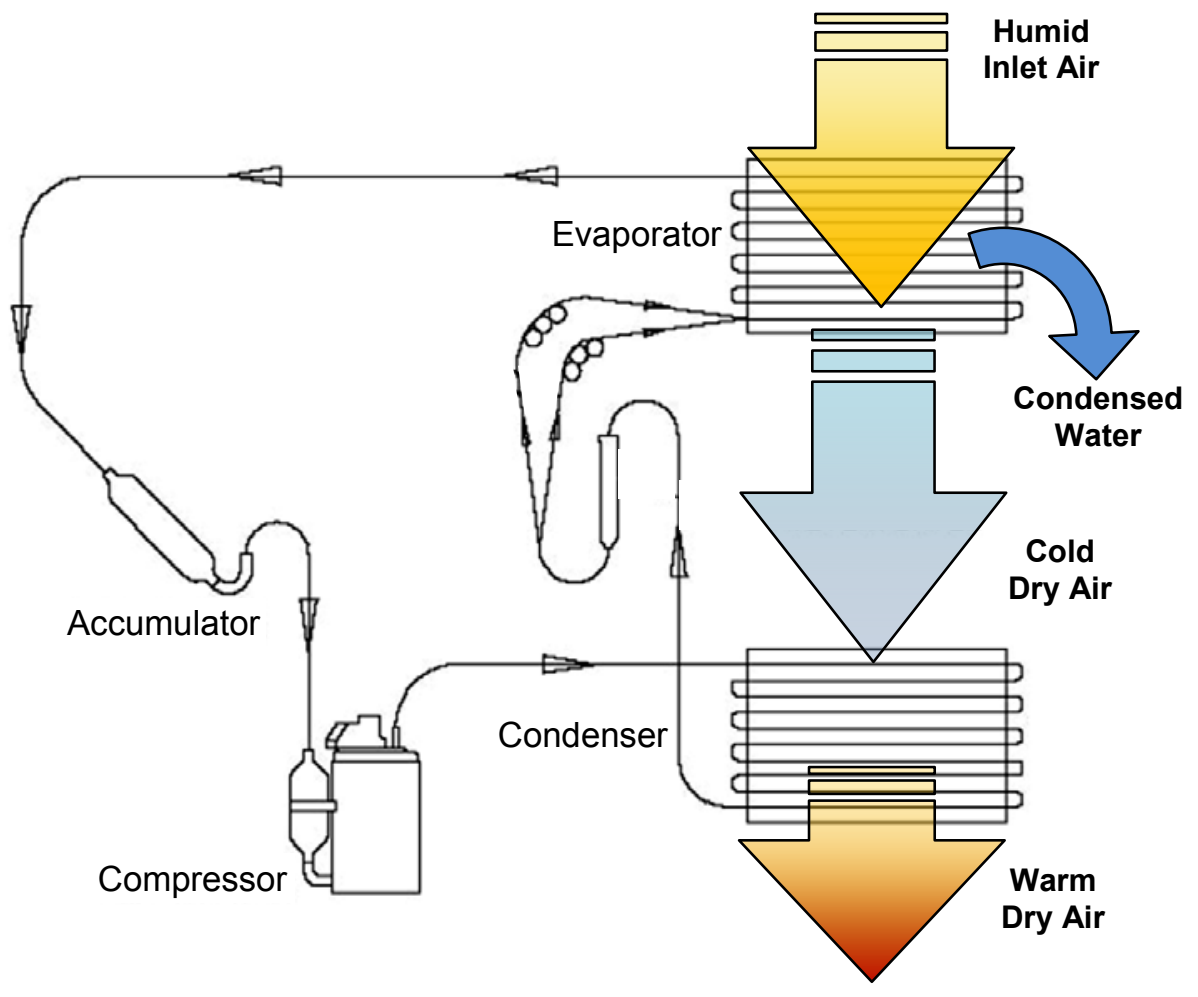

Figure 3. $\mathrm{XT} 150 \mathrm{H}$ process schematic. An intermediate air-to-air heat exchanger, which spans the evaporator, is not shown. 


\section{Test Description}

A Thermastor Ultra-Aire XT150H dehumidifier was tested at the National Renewable Energy Laboratory in the Thermal Transfer Lab with funding from DOE for the Building America program. The method of test followed ANSI/AHAM DH-1-2003, except as listed below. Air was supplied at tightly controlled psychrometric states and the performance was measured over a period of up to 50 minutes at each of 12 test conditions. These test conditions were chosen to represent some typical operating conditions, as well as to bracket those conditions for more accurate interpolation modeling. A summary of the test data is presented in Appendix A.

Inlet and outlet air flow rates were measured using laminar flow elements. An initial set of tests showed that the unit's fan drew 330 CFM at zero external static pressure drop. For subsequent tests, air flow was maintained by the lab's inlet fan to provide appropriate mass flow to the dehumidifier's return duct. Unit pressure was controlled to ambient pressure by the lab's outlet fan, to minimize potential errors from small air leaks. Air Mass Balance was defined as the ratio of instantaneous inlet air mass flow rate to instantaneous outlet air mass flow rate.

Dew point was monitored on both inlet and outlet airstreams using chilled mirror hygrometers, providing a precise measure of air humidity. Condensate flow rate was measured using a coriolis flowmeter. Condensate was also collected in a container and weighed after each test run, in accordance with ANSI/AHAM DH-1-2003. These results were recorded but not used in the ensuing analysis, for two reasons. First, condensate collection provides average condensate production rather than instantaneous. Secondly, to obtain similar accuracies to the coriolis flowmeter's, test runs needed to be quite lengthy. Use of a coriolis flowmeter allowed test times of minutes, not hours. A Moisture Mass Balance was defined as the ratio of instantaneous inlet air moisture mass flow rate to the sum of outlet air moisture mass flow rate and condensate flow rate.

Temperatures of the well-mixed inlet and outlet airstreams were measured using a thermocouple array within ductwork near the unit. Inlet and outlet static pressure were measured using pitot tubes near the unit. Enthalpy was calculated for the airstreams using ASHRAE standard formulas. Electric power was measured using a power meter. An Energy Balance was defined as the ratio of the sum of inlet air energy rate and electric power to the sum of outlet air energy and condensate energy rates.

Photos of the experimental setup are shown in Appendix B.

Instantaneous Air Mass and Energy Balances in all cases were achieved to within $0.5 \%$ and $1.6 \%$, respectively. Instantaneous Moisture Balance was not met as closely due to moisture retention within the unit and piping systems caused by condensate surface tension, but still fell within $5 \%$. A summary of these balances is provided in Table 1.

Table 1. Summary of Measured Parameter Balances

\begin{tabular}{|l|c|c|c|c|}
\hline & Average & Minimum & Maximum & Standard Deviation \\
\hline Energy Balance & 0.998 & 0.984 & 1.005 & 0.006 \\
\hline Air Mass Balance & 1.000 & 0.995 & 1.004 & 0.003 \\
\hline Moisture Mass Balance & 1.015 & 0.984 & 1.047 & 0.025 \\
\hline
\end{tabular}




\section{Results}

The experimental data was fit to a biquadratic equation. This is a typical form used to model HVAC equipment. However, in the case of a packaged dehumidifier the dry bulb and dew point temperatures of significance both refer to the dehumidifier inlet air. (Typical parameters of significance for unitary air conditioners are: indoor air dew point and outdoor air dry bulb temperature.) Six performance parameters were investigated for applicability of the model. The performance curve, a function of inlet dry bulb temperature $\left({ }^{\circ} \mathrm{C}\right)$ and inlet dew point temperature $\left({ }^{\circ} \mathrm{C}\right)$, is:

$$
\text { Parameter }=A \times T_{D B}+B \times T_{D B}^{2}+C \times T_{D e w}+D \times T_{D e w}^{2}+E \times T_{D B} \times T_{D e w}+F
$$

Curve fit coefficients are shown in Table 2. Electric Power Consumption includes fan power at 0 " water static pressure across the packaged unit. Since the outlet air has a higher temperature than the inlet air, Sensible Load Removal is seen to be negative at all times. The equations for Latent and Sensible Load Removal may be summed to achieve a Total Load Removal equation, the coefficients of which are shown below for convenience. (Note that "Sensible Load Removed" and "Total Load Removed" have a negative value at all operating conditions, since the outlet air is warmer than inlet air by the latent heat removed plus electric power consumed.) Further, the efficiency metrics of condensate production in pints/day and liters/kWh were fit to the same form with good correlation. This will allow efficiency comparison of dehumidifiers at conditions away from the ANSI/AHAM DH-1-2003 test point: $80^{\circ} \mathrm{F}$ dry bulb, $69.6^{\circ} \mathrm{F}$ wet bulb $\left(64.55^{\circ} \mathrm{F}\right.$ dew point, $\left.59.8 \% \mathrm{RH}\right)$.

Table 2. Curve Fit Coefficients and Coefficient of Determination for Measured Effects of the Ultra-Aire XT150H Dehumidifier

\begin{tabular}{|c|c|c|c|c|c|c|}
\hline $\begin{array}{c}\text { Parameter: } \\
\text { Coefficient }\end{array}$ & $\begin{array}{c}\text { Electric Power } \\
\text { Consumption } \\
\mathbf{( k W )}\end{array}$ & $\begin{array}{c}\text { Total Load } \\
\text { Removed } \\
\mathbf{( k W )}\end{array}$ & $\begin{array}{c}\text { Sensible Load } \\
\text { Removed } \\
\mathbf{( k W )}\end{array}$ & $\begin{array}{c}\text { Latent Load } \\
\text { Removed } \\
\mathbf{( k W )}\end{array}$ & $\begin{array}{c}\text { Estimated } \\
\text { Production } \\
\text { (pints/day) }\end{array}$ & $\begin{array}{c}\text { Efficiency } \\
\mathbf{( L / k W h )}\end{array}$ \\
\hline A & 0.000647 & 0.0340 & 0.0631 & -0.0290 & -1.21 & -0.0845 \\
\hline B & 0.000143 & -0.000675 & -0.000473 & -0.000202 & -0.0244 & $8.32 \mathrm{E}-5$ \\
\hline C & 0.00343 & -0.0254 & -0.166 & 0.140 & 7.87 & 0.279 \\
\hline D & 0.000212 & -0.000407 & -0.000997 & 0.000589 & 0.0715 & -0.00158 \\
\hline E & $1.868 \mathrm{E}-5$ & 0.000773 & 0.00171 & -0.000935 & -0.0330 & -0.00169 \\
\hline F & 0.567 & -1.05 & -1.79 & 0.741 & 49.8 & 2.059 \\
\hline r-squared & 0.998 & 0.987 & 0.999 & 0.999 & 0.998 & 0.998 \\
\hline
\end{tabular}

Plots of these curves and comparisons of model results to the measured data are presented in Appendix C. With R-Squared values (shown above) demonstrating close agreement of the model with measured performance, these curves are sufficient to simulate the performance of the equipment in annual simulations under full-load conditions. Cycling measurements are needed to complete the unit's model for part-load conditions.

Version 4.0.0 of EnergyPlus, an annual whole building simulation tool, includes a zone dehumidifier component model for the first time [2]. The component model simulates the thermal performance and electric power of a conventional DX dehumidifier. Performance curves 
are used to scale the rating point performance to simulate various operating conditions. The rating point performance was determined using test point 13a, as shown in Appendix A. Performance curves are used to predict the water removal rate (L/day) and energy factor $(\mathrm{L} / \mathrm{kWh})$ fractions and should be approximately equal to a value of 1 at the rated operating condition. The performance curve implemented by the EnergyPlus model, a function of inlet dry bulb temperature $\left({ }^{\circ} \mathrm{C}\right)$ and inlet relative humidity $(0-100 \%)$, is:

$$
\text { Parameter }=A+B \times T_{D B}+C \times T_{D B}^{2}+D \times R H+E \times(R H)^{2}+F \times T_{D B} \times R H
$$

The model uses a cubic function to predict the part load fraction as a function of the part load ratio. The part load fraction performance curve coefficients recommended in the EnergyPlus documentation were used since part load performance was not measured during the experimental testing.

The performance curve fit coefficients are shown in Table 3. The R-squared values indicate the performance curves have accurately captured the experimental performance.

Table 3: Curve Fit Coefficients and Coefficient of Determination for EnergyPlus Performance Curves for the Ultra-Aire XT150H Dehumidifier

\begin{tabular}{|l|c|c|}
\hline $\begin{array}{c}\text { Parameter: } \\
\text { Coefficient }\end{array}$ & $\begin{array}{c}\text { Water Removal } \\
\text { Rate Fraction }\end{array}$ & $\begin{array}{c}\text { Energy Factor } \\
\text { Fraction }\end{array}$ \\
\hline $\mathrm{A}$ & -1.281357458 & -2.743752887 \\
\hline $\mathrm{B}$ & 0.032064893 & 0.114491512 \\
\hline $\mathrm{C}$ & -0.000280794 & -0.001456831 \\
\hline $\mathrm{D}$ & 0.028356002 & 0.053860412 \\
\hline $\mathrm{E}$ & -0.000134939 & -0.000244965 \\
\hline $\mathrm{F}$ & 0.000271496 & -0.000362021 \\
\hline \hline r-squared & 0.998 & 0.989 \\
\hline
\end{tabular}

Appendix D contains plots displaying the accuracy of the model. The average relative error in the water removal rate is $1.4 \%$ with a maximum error of $3.74 \%$ and the average relative error in the energy factor is $2.67 \%$ with a maximum error of $7.46 \%$. 


\section{Other Observations}

The manufacturer's specifications were confirmed except for one. The Unit Under Test did not provide air flow at the rated $415 \mathrm{CFM}$ at 0 in.H2O static pressure. Instead, 325335 CFM was measured when the unit was presented with no pressure drop. Since an installed unit's pressure drop is installation-specific, it is not possible to include the effect of other differential pressure conditions in an annual simulation. However, the low volumetric flow rate combined with large duct sizes that would typically be used in homes requiring this dehumidifier implies that assuming a low pressure drop is not unreasonable. 


\section{Discussion and Conclusions}

The ThermaStor Ultra-Aire XT150H Dehumidifier achieved its rated performance at test conditions. A numerical model was used to fit the experimental data within a small error. Therefore, it is assumed that the model is a reasonable representation of the unit and may be used in annual energy simulations.

It is clear from the plots in Appendix $C$ that unit performance is maximized at high inlet air dew point, regardless of dry bulb temperature. It is easier for the unit to bring the evaporator coil's temperature below the dew point in those cases. At a given dew point, lower dry bulb temperatures lead to higher efficiency for the same reason - less sensible cooling is needed to bring the air to $100 \%$ relative humidity.

The dehumidifier operates by returning the heat of vaporization, which is absorbed into the refrigerant as the water condenses out of the air, back to the airstream in the form of sensible heat. The more moisture that is removed, the more sensible heat must be rejected downstream. This reheat process is ideally a balanced enthalpy exchange. However, the dehumidifier also heats the outlet air via the fan motor and compressor power. As a result, the outlet air enthalpy is increased in direct proportion to the unit's power consumption. The unit will always apply a positive sensible load in excess of the latent load removal.

The ducted outlet of the unit was extremely warm, and extra insulation had to be applied to restrict heat loss and achieve proper energy balance. This high temperature is demonstrated by the high sensible heat load (large negative sensible heat removal) from the model. Within the expected temperature range of this unit's residential usage, it is seen that the sensible load applied to the house is between 2.0 and $3.5 \mathrm{~kW}$. In a home with typical loads, the central cooling system would provide sufficient dehumidification during peak periods, thus this sensible load poses little concern. It is advisable for an HVAC designer to consider the sensible heat impact of a dehumidifier on occupant comfort, particularly during shoulder seasons when the air conditioner operates in part load.

There may be opportunities for improvement in efficiency through design modifications, pending future work including inspection and analysis of the inner systems. This has not been initiated because of the desire to test cycling behavior of the unit, which will require modifications to the laboratory apparatus and adjustment of testing protocols. That work is ongoing. The controls of the dehumidifier will play a role in the thermal cycling performance and condensate re-evaporation. These effects are not yet included in the model. 


\section{References}

[1] Ultra-Aire XT150H Installer's \& Owner's Manual. Available at: http://www.ultra-aire.com/images/pdfs/UA-XT150H_manual.pdf. Accessed 5/15/2008.

[2] EnergyPlus is a DOE-sponsored simulation program, freely available at http://apps1.eere.energy.gov/buildings/energyplus/. Version 4.0.0 was used for this work. 


\section{Appendix A - Summary of Measured and Calculated Test Data}

The data points used for testing are shown on a psychrometric chart in Figure 4. Psychrometric chart showing test points. A summary table of results is presented below in Table 4 and Table 5 .

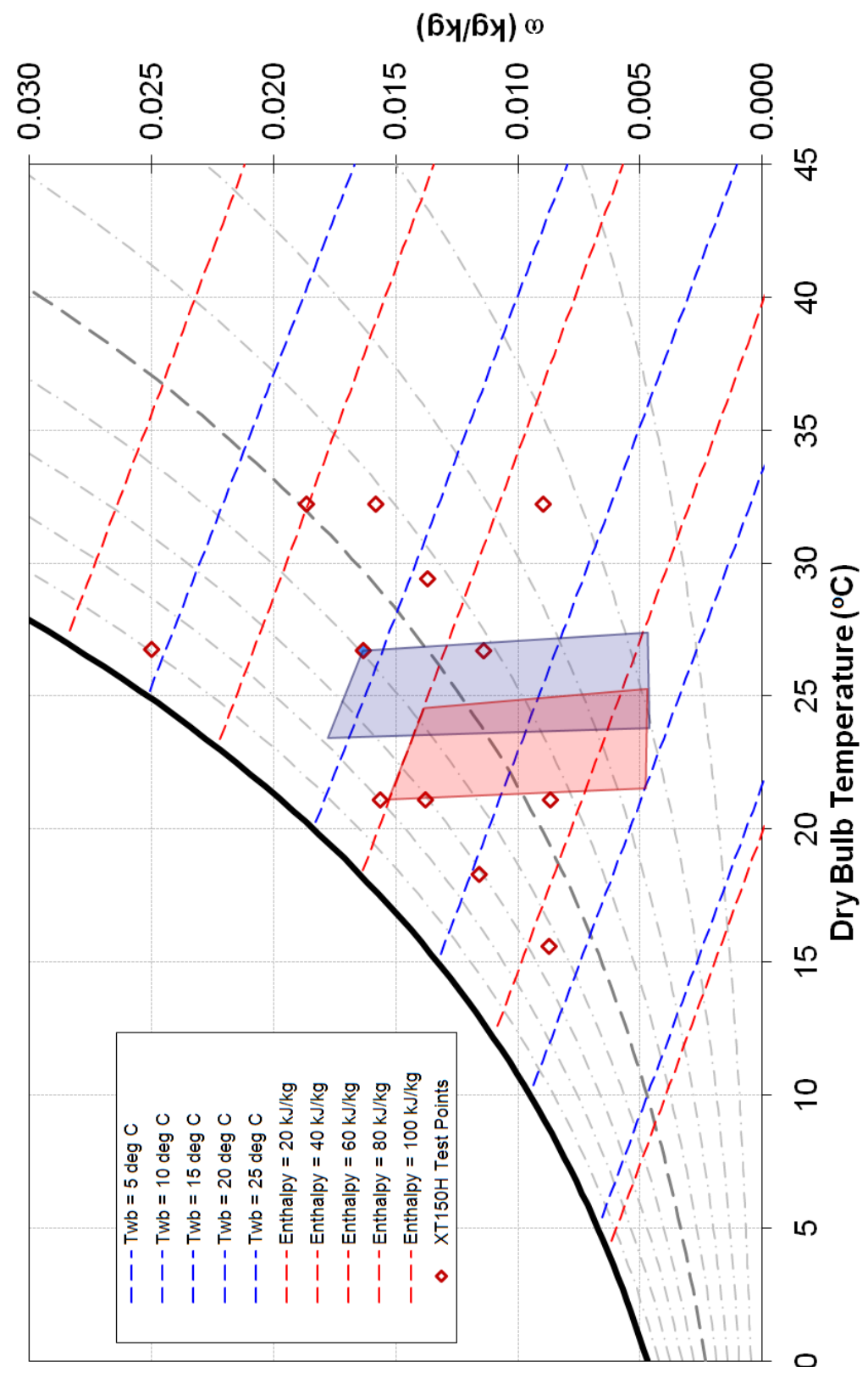

Figure 4. Psychrometric chart showing test points. ASHRAE thermal comfort regions are shaded in blue (cooling) and red (heating). 
Table 4. Summary of Test Data

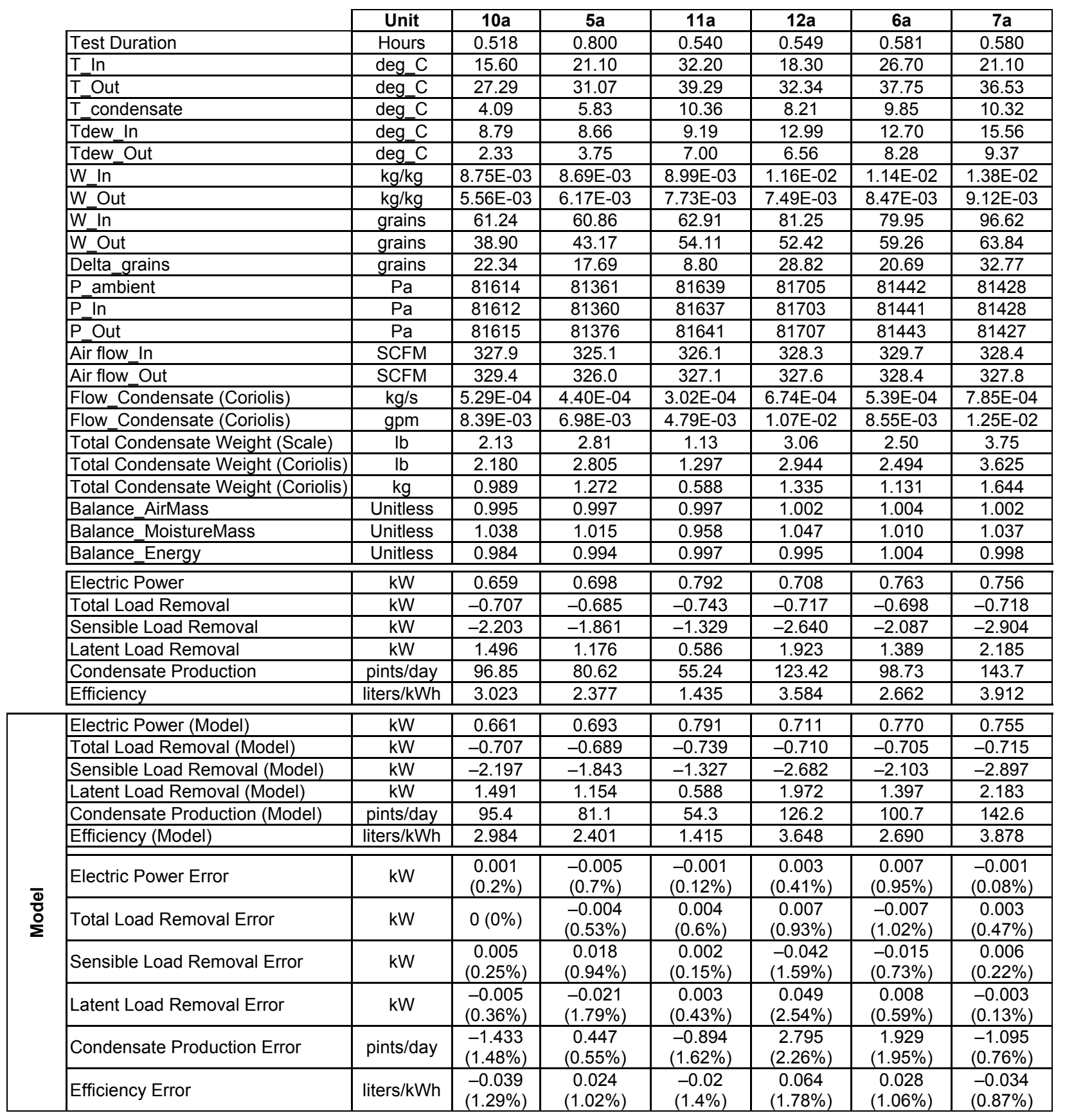


Table 5. Summary of Test Data (continued)

\begin{tabular}{|c|c|c|c|c|c|c|c|}
\hline & Unit & $2 a$ & $8 a$ & $9 a$ & $13 a$ & $14 a$ & $15 a$ \\
\hline Test Duration & Hours & 0.497 & 0.465 & 0.231 & 0.483 & 0.499 & 0.350 \\
\hline T_In & deg_C & 29.40 & 21.10 & 32.20 & 26.71 & 32.21 & 26.75 \\
\hline T_Out & deg_C & 41.73 & 38.31 & 45.34 & 42.28 & 47.50 & 47.46 \\
\hline T_condensate & deg_C & 12.54 & 11.81 & 14.97 & 13.94 & 16.92 & 23.63 \\
\hline Tdew_In & deg_C & 15.45 & 17.46 & 17.65 & 18.20 & 20.32 & 25.04 \\
\hline Tdew_Out & deg_C & 11.17 & 11.04 & 13.55 & 13.03 & 16.02 & 19.99 \\
\hline W In & $\mathrm{kg} / \mathrm{kg}$ & $1.37 \mathrm{E}-02$ & \begin{tabular}{|l|}
$1.57 \mathrm{E}-02$ \\
\end{tabular} & $1.58 \mathrm{E}-02$ & $1.63 \mathrm{E}-02$ & $1.87 \mathrm{E}-02$ & $2.50 \mathrm{E}-02$ \\
\hline W_Out & $\mathrm{kg} / \mathrm{kg}$ & $1.03 E-02$ & $1.02 \mathrm{E}-02$ & $1.21 \mathrm{E}-02$ & $1.16 \mathrm{E}-02$ & $1.41 \mathrm{E}-02$ & 1.82E-02 \\
\hline W In & grains & 96.00 & 109.54 & 110.82 & 114.26 & 130.67 & 175.00 \\
\hline W_Out & grains & 72.21 & 71.65 & 84.75 & 81.43 & 99.03 & 127.39 \\
\hline Delta_grains & grains & 23.79 & 37.91 & 26.10 & 32.83 & 31.64 & 47.61 \\
\hline$P$ _ambient & $\mathrm{Pa}$ & 81371 & 81307 & 81342 & 81765 & 81894 & 82211 \\
\hline P_In & $\mathrm{Pa}$ & 81372 & 81308 & 81343 & 81763 & 81892 & 82209 \\
\hline P_Out & $\mathrm{Pa}$ & 81370 & 81307 & 81340 & 81768 & 81897 & 82213 \\
\hline Air flow_In & SCFM & 327.9 & 328.1 & 329.8 & 327.5 & 327.2 & 335.9 \\
\hline Air flow_Out & SCFM & 327.0 & 328.2 & 329.2 & 327.2 & 327.1 & 336.0 \\
\hline Flow_Condensate (Coriolis) & $\mathrm{kg} / \mathrm{sec}$ & $6.46 \mathrm{E}-04$ & $8.81 \mathrm{E}-04$ & $6.80 \mathrm{E}-04$ & $8.41 \mathrm{E}-04$ & 8.49E-04 & 1.19E-03 \\
\hline Flow_Condensate (Coriolis) & gpm & 1.03E-02 & 1.40E-02 & 1.08E-02 & 1.34E-02 & $1.35 \mathrm{E}-02$ & 1.90E-02 \\
\hline Total Condensate Weight (Scale) & Ibs & 2.59 & 3.50 & 2.81 & 3.31 & 3.31 & 3.44 \\
\hline $\begin{array}{l}\text { Total Condensate Weight } \\
\text { (Coriolis) }\end{array}$ & Ibs & 2.554 & 3.262 & 1.251 & 3.231 & 3.373 & 3.325 \\
\hline $\begin{array}{l}\text { Total Condensate Weight } \\
\text { (Coriolis) }\end{array}$ & $\mathrm{kg}$ & 1.159 & 1.480 & 0.568 & 1.465 & 1.530 & 1.508 \\
\hline Balance_AirMass & Unitless & 1.003 & 1.000 & 1.002 & 1.001 & 1.000 & 1.000 \\
\hline Balance_MoistureMass & Unitless & 0.997 & 1.046 & 1.007 & 1.011 & 0.997 & 1.022 \\
\hline Balance_Energy & Unitless & 1.004 & 0.997 & 1.005 & 1.000 & 1.001 & 0.996 \\
\hline Electric Power & $\mathrm{kW}$ & 0.820 & 0.779 & 0.874 & 0.831 & 0.907 & 0.916 \\
\hline Total Load Removal & $\mathrm{kW}$ & -0.731 & -0.716 & -0.736 & -0.744 & -0.776 & -0.788 \\
\hline Sensible Load Removal & $\mathrm{kW}$ & -2.318 & -3.240 & -2.486 & -2.927 & -2.875 & -3.997 \\
\hline \begin{tabular}{|l} 
Latent Load Removal \\
\end{tabular} & $\mathrm{kW}$ & 1.587 & 2.524 & 1.750 & 2.183 & 2.098 & 3.209 \\
\hline Condensate Production & pints/day & 118.4 & 161.3 & 124.8 & 154.2 & 155.7 & 219.2 \\
\hline Efficiency & liters/kWh & 2.967 & 4.257 & 2.936 & 3.814 & 3.525 & 4.910 \\
\hline
\end{tabular}

\begin{tabular}{|c|c|c|c|c|c|c|c|c|}
\hline \multirow{12}{*}{$\begin{array}{l}\bar{d} \\
\overline{0} \\
\sum\end{array}$} & Electric Power (Model) & $\mathrm{kW}$ & 0.821 & 0.775 & 0.873 & 0.828 & 0.905 & 0.918 \\
\hline & Total Load Removal (Model) & $\mathrm{kW}$ & -0.726 & -0.728 & -0.753 & -0.730 & -0.768 & -0.790 \\
\hline & Sensible Load Removal (Model) & $\mathrm{kW}$ & -2.336 & -3.203 & -2.478 & -2.922 & -2.867 & -4.009 \\
\hline & Latent Load Removal (Model) & $\mathrm{kW}$ & 1.610 & 2.476 & 1.725 & 2.192 & 2.099 & 3.220 \\
\hline & Condensate Production (Model) & pints/day & 117.1 & 160.9 & 128.4 & 151.4 & 153.8 & 220.2 \\
\hline & Efficiency (Model) & liters/kWh & 2.937 & 4.259 & 3.024 & 3.754 & 3.483 & 4.930 \\
\hline & Electric Power Error & $\mathrm{kW}$ & $\begin{array}{c}0.001 \\
(0.16 \%)\end{array}$ & $\begin{array}{c}-0.004 \\
(0.48 \%)\end{array}$ & $\begin{array}{c}0 \\
(0.05 \%)\end{array}$ & $\begin{array}{c}-0.003 \\
(0.35 \%)\end{array}$ & $\begin{array}{c}-0.002 \\
(0.18 \%)\end{array}$ & $\begin{array}{c}0.002 \\
(0.25 \%)\end{array}$ \\
\hline & Total Load Removal Error & kW & $\begin{array}{c}0.005 \\
(0.66 \%) \\
\end{array}$ & $\begin{array}{c}-0.012 \\
(1.65 \%) \\
\end{array}$ & $\begin{array}{c}-0.017 \\
(2.36 \%) \\
\end{array}$ & $\begin{array}{c}0.014 \\
(1.86 \%) \\
\end{array}$ & $\begin{array}{c}0.009 \\
(1.1 \%) \\
\end{array}$ & $\begin{array}{c}-0.002 \\
(0.24 \%)\end{array}$ \\
\hline & Sensible Load Removal Error & $\mathrm{kW}$ & $\begin{array}{c}-0.018 \\
(0.77 \%)\end{array}$ & $\begin{array}{c}0.037 \\
(1.14 \%)\end{array}$ & $\begin{array}{c}0.008 \\
(0.31 \%)\end{array}$ & $\begin{array}{c}0.004 \\
(0.15 \%)\end{array}$ & $\begin{array}{c}0.008 \\
(0.27 \%)\end{array}$ & $\begin{array}{c}-0.013 \\
(0.31 \%)\end{array}$ \\
\hline & Latent Load Removal Error & $\mathrm{kW}$ & $\begin{array}{c}0.023 \\
(1.44 \%) \\
\end{array}$ & $\begin{array}{c}-0.049 \\
(1.93 \%) \\
\end{array}$ & $\begin{array}{c}-0.025 \\
(1.43 \%) \\
\end{array}$ & $\begin{array}{c}0.01 \\
(0.44 \%) \\
\end{array}$ & $\begin{array}{c}0.001 \\
(0.05 \%) \\
\end{array}$ & $\begin{array}{c}0.011 \\
(0.34 \%) \\
\end{array}$ \\
\hline & Condensate Production Error & pints/day & $\begin{array}{c}-1.23 \\
(1.04 \%)\end{array}$ & $\begin{array}{l}-0.485 \\
(0.3 \%) \\
\end{array}$ & $\begin{array}{c}3.522 \\
(2.82 \%) \\
\end{array}$ & $\begin{array}{l}-2.774 \\
(1.8 \%) \\
\end{array}$ & $\begin{array}{c}-1.822 \\
(1.17 \%) \\
\end{array}$ & $\begin{array}{c}1.043 \\
(0.48 \%) \\
\end{array}$ \\
\hline & Efficiency Error & liters/kWh & $\begin{array}{c}-0.029 \\
(1.03 \%)\end{array}$ & $\begin{array}{c}0.002 \\
(0.05 \%)\end{array}$ & $\begin{array}{c}0.088 \\
(2.99 \%)\end{array}$ & $\begin{array}{c}-0.06 \\
(1.58 \%)\end{array}$ & $\begin{array}{c}-0.042 \\
(1.18 \%)\end{array}$ & $\begin{array}{c}0.02 \\
(0.4 \%)\end{array}$ \\
\hline
\end{tabular}




\section{Appendix B - Photos of Experimental Setup}

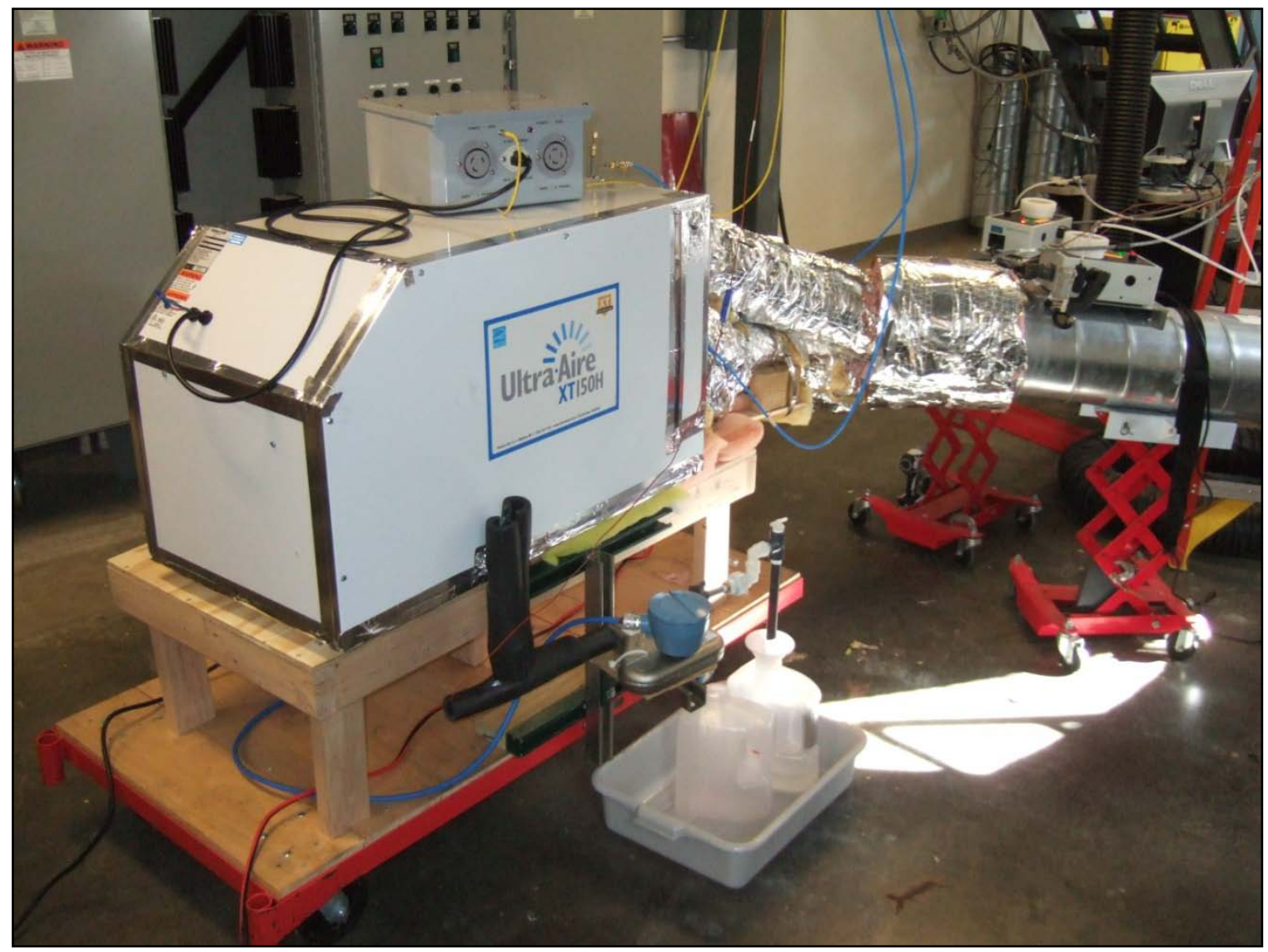

Figure 5. Photograph of Ultra-Aire XT150H test setup

A stand was constructed to elevate the unit so flow could be measured and collected. The temperature of the flowing condensate was measured in the trap. This piping was insulated to maintain condensate temperature up to a coriolis flowmeter. The condensate was collected downstream in the jug seen in the lower center of the image, and weighed after the test. All seams in the XT150H's sheet metal box were sealed with aluminum tape, to prevent air leakage and thus maintain an accurate air mass balance. The gray box sitting on top of the dehumidifier is the power meter. 


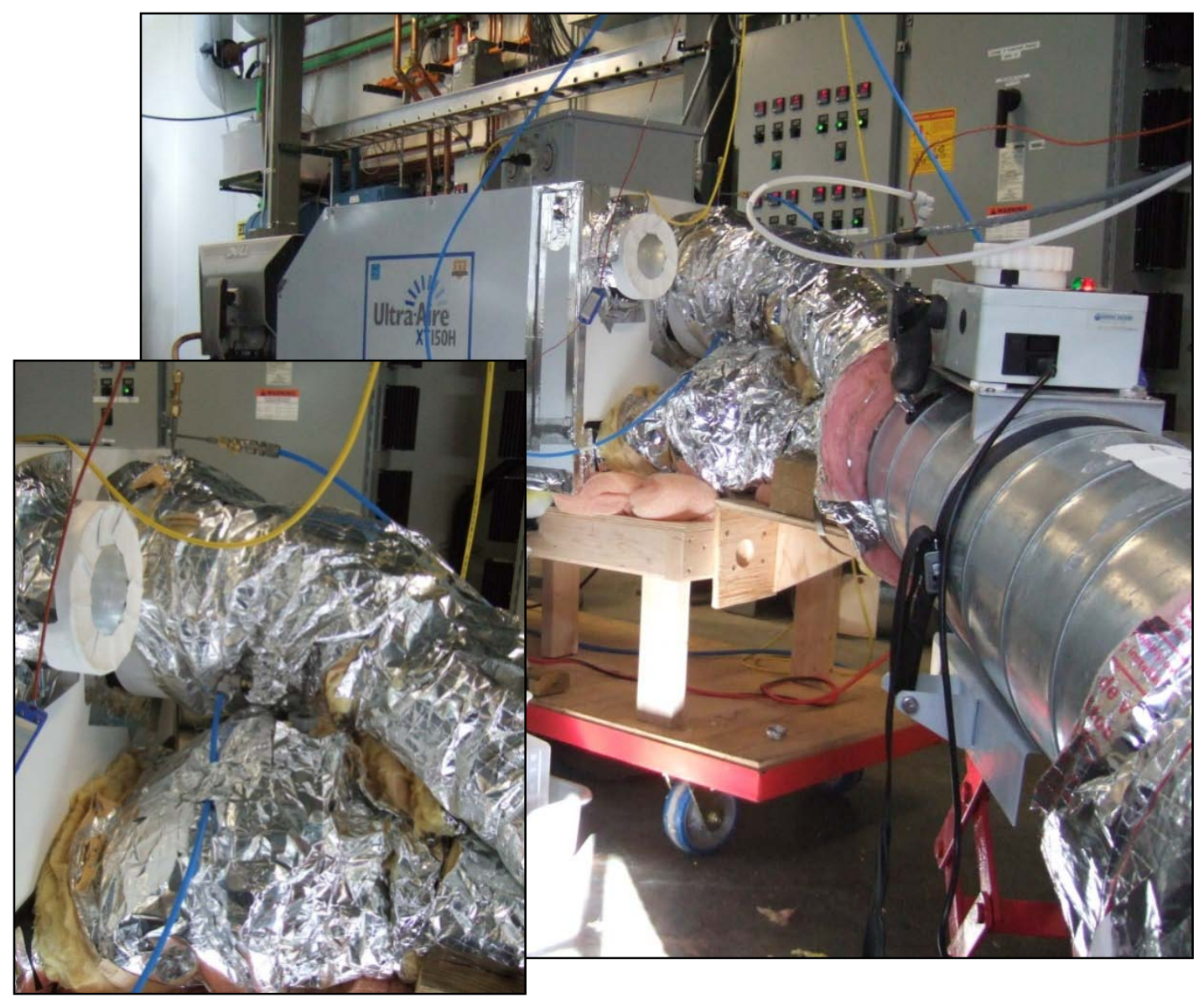

Figure 6. Photograph of Ultra-Aire $\mathrm{XT150H}$ test setup

The rigid ductwork to the right of the image is a mixing section, at the end of which temperature and humidity are measured. Thick insulation was applied to the ductwork after that measurement to prevent heat loss and condensation prior to the dehumidifier inlet. Similarly, insulated ductwork routes the outlet airstream to a mixing section where outlet temperature and humidity are measured. The inset image shows pitot tube connections for pressure measurement immediately at the unit's inlet and outlet. The blue tubing connects the pitot tubes to pressure transducers. 


\section{Appendix C - Plots of Data Fit Surfaces and Model Comparisons}
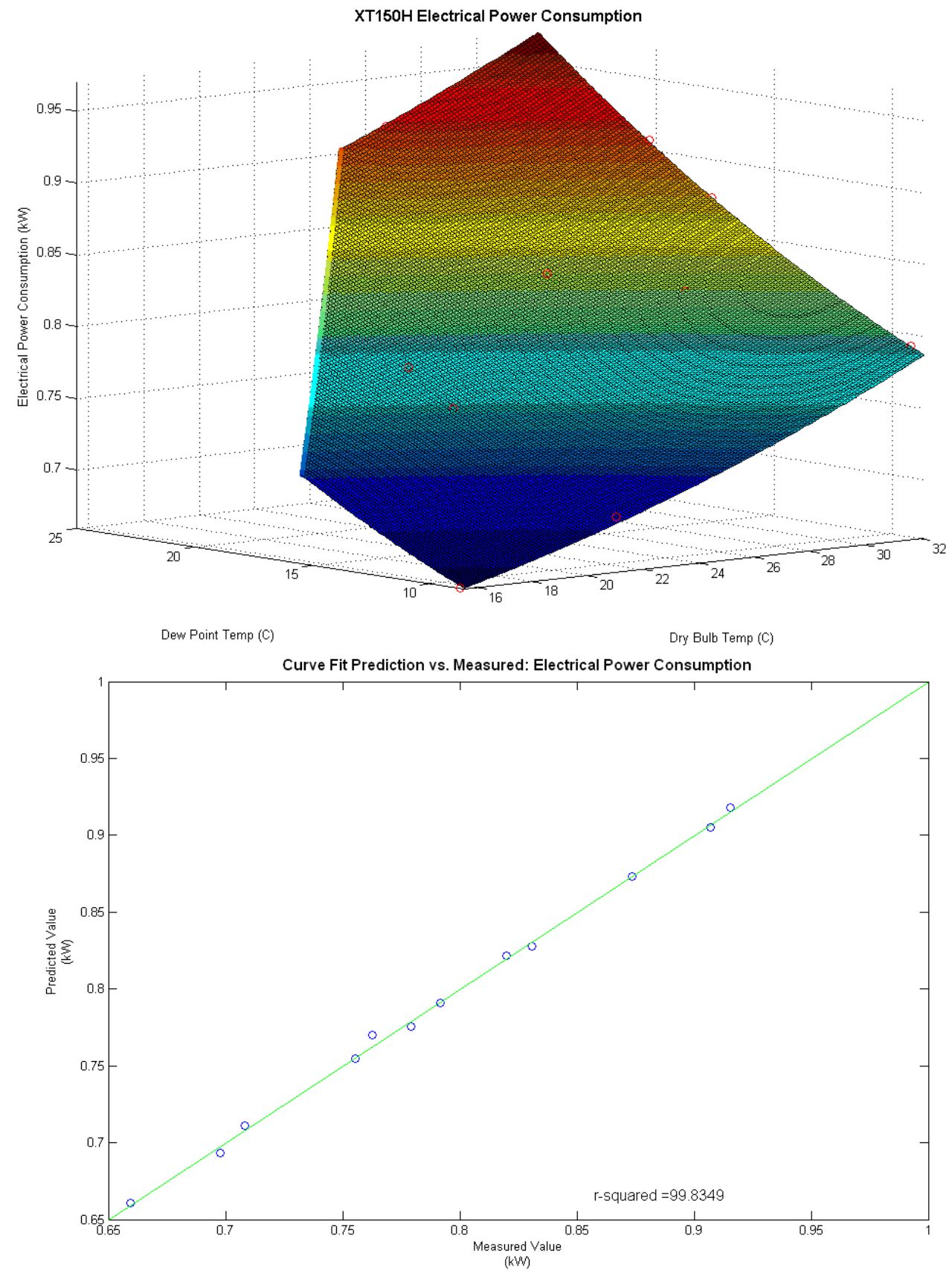

Figure 7. Electrical power consumption (kW) 


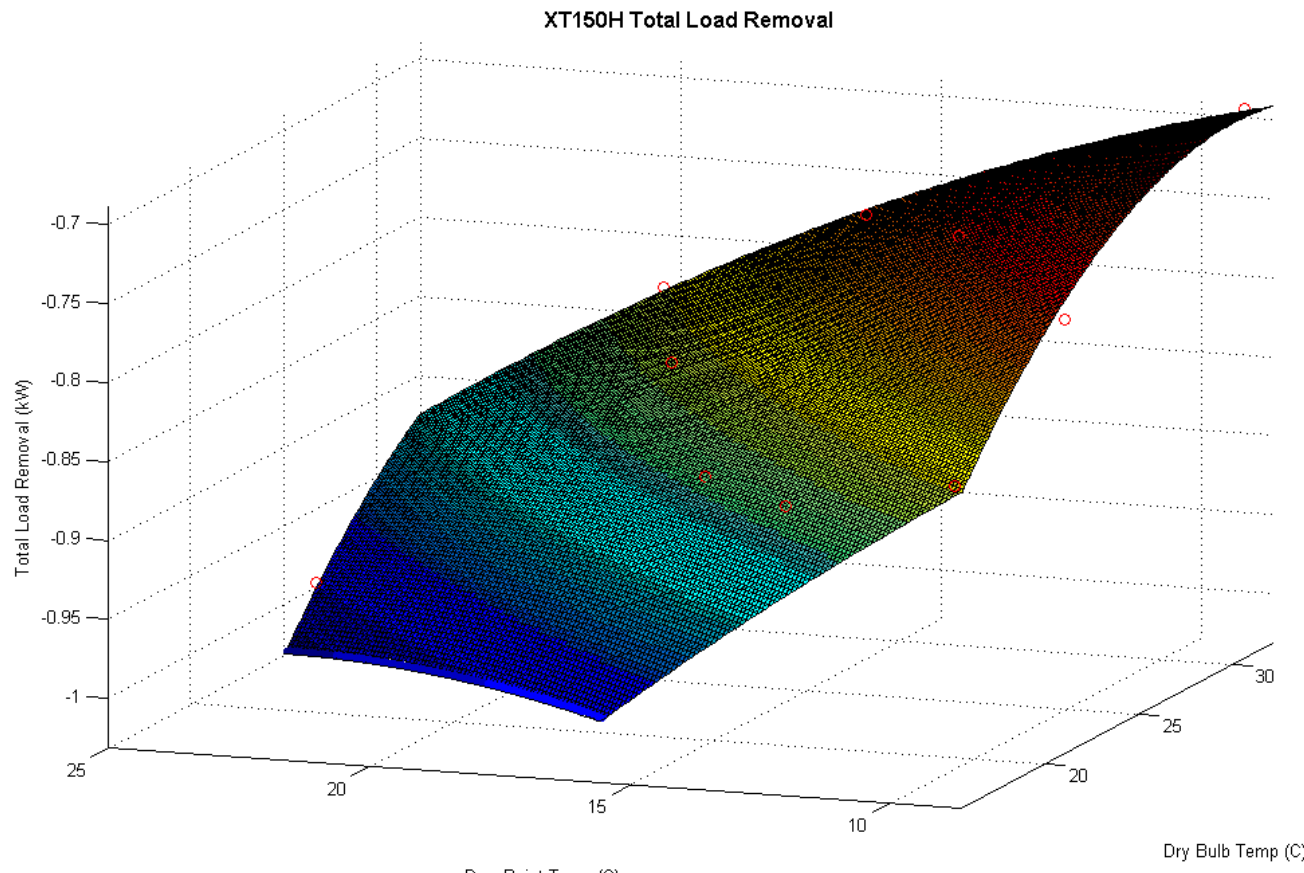

Dew Point Temp (C)

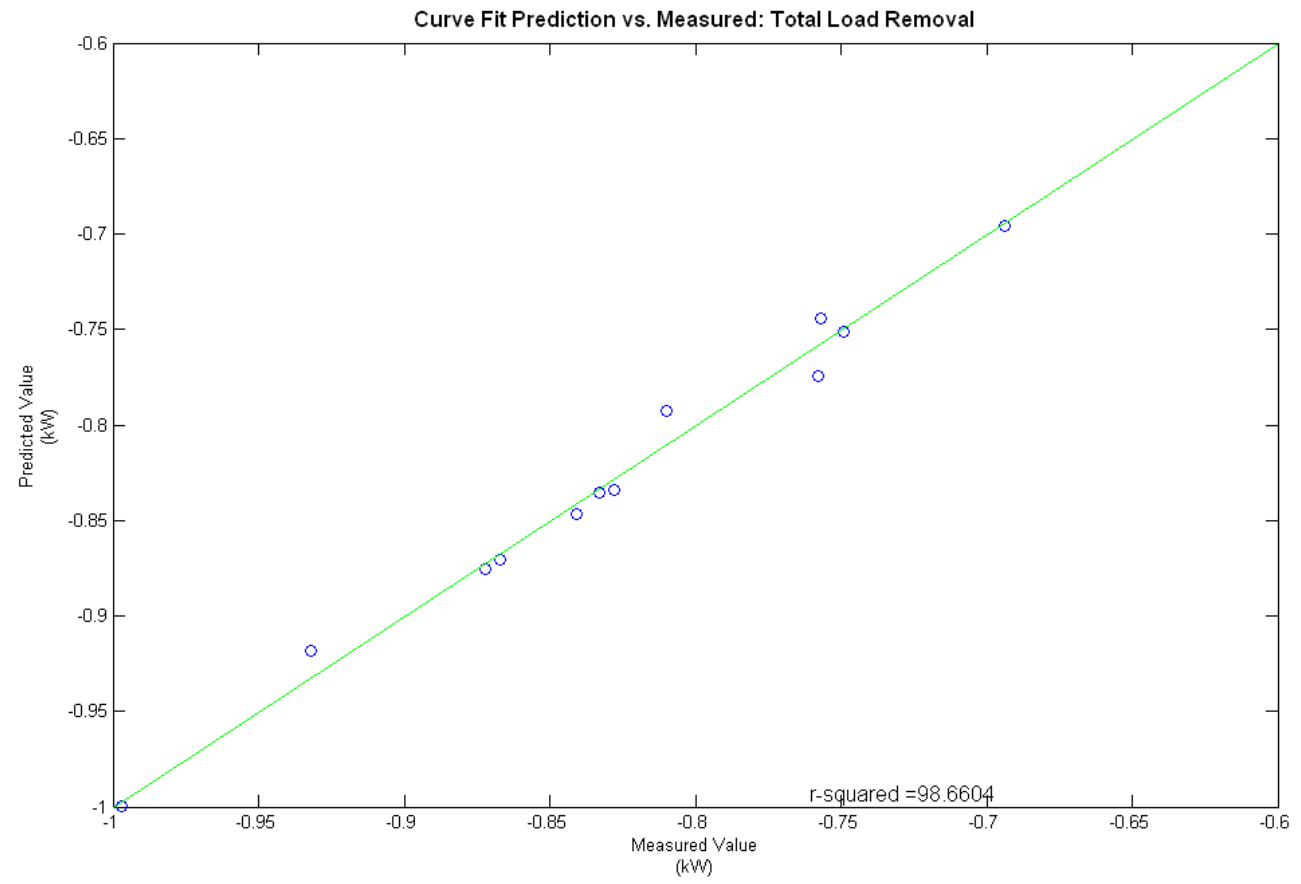

Figure 8. Total load removal (kW) 

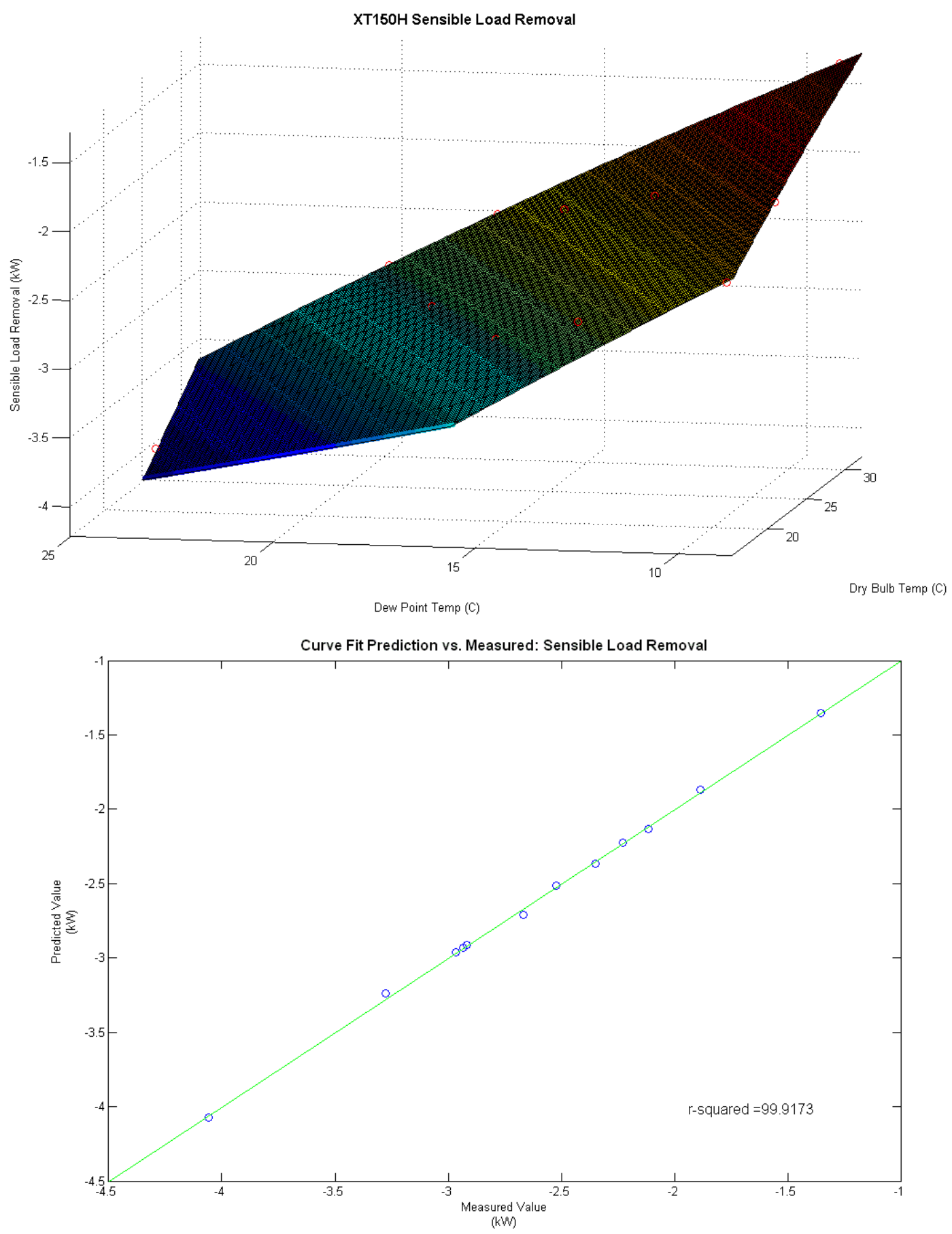

Figure 9. Sensible load removal (kW) 

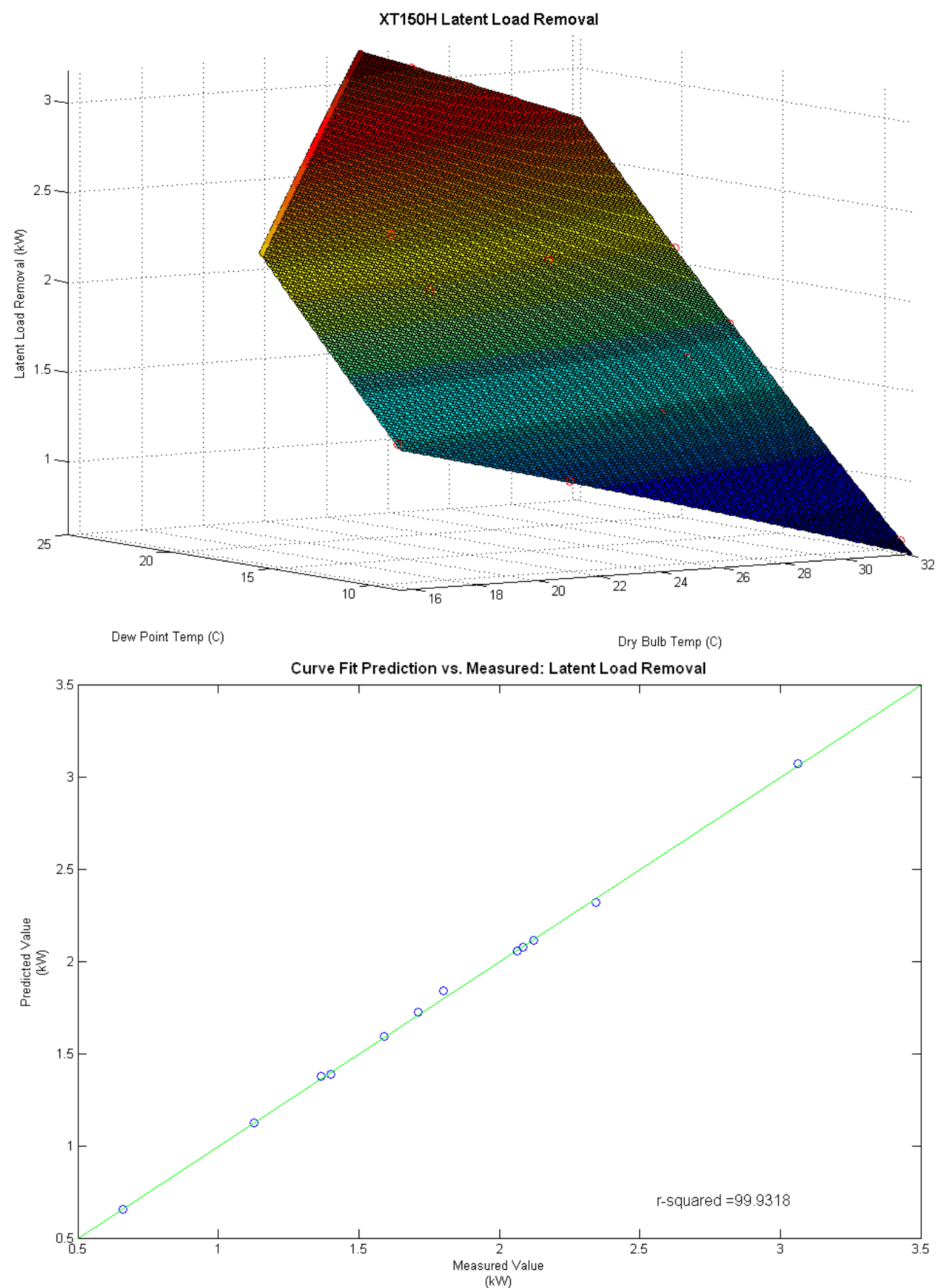

Figure 10. Latent load removal (kW) 

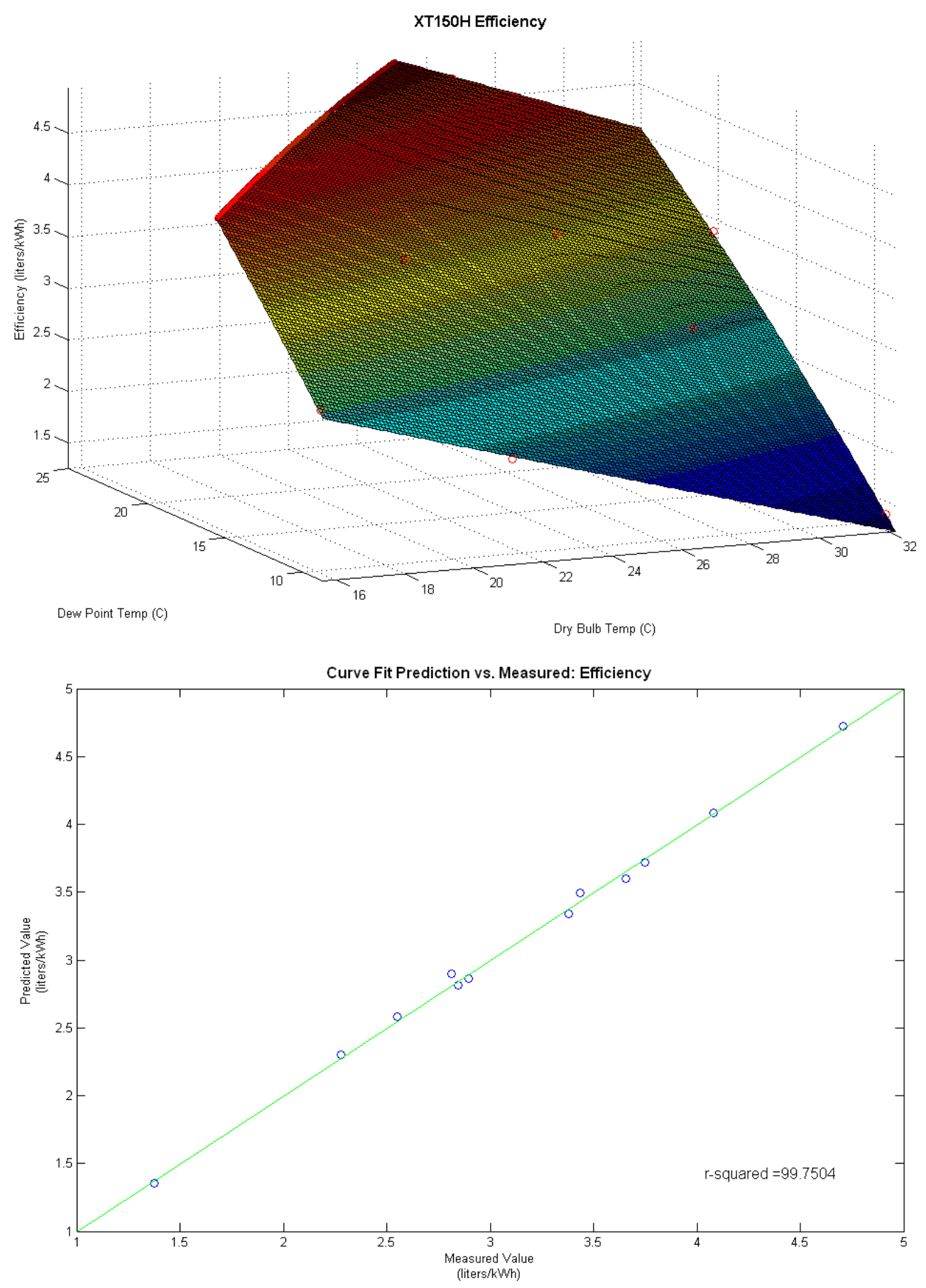

Figure 11. Efficiency (L/kWh) 


\section{Appendix D - Plots of EnergyPlus Model Performance Comparisons}
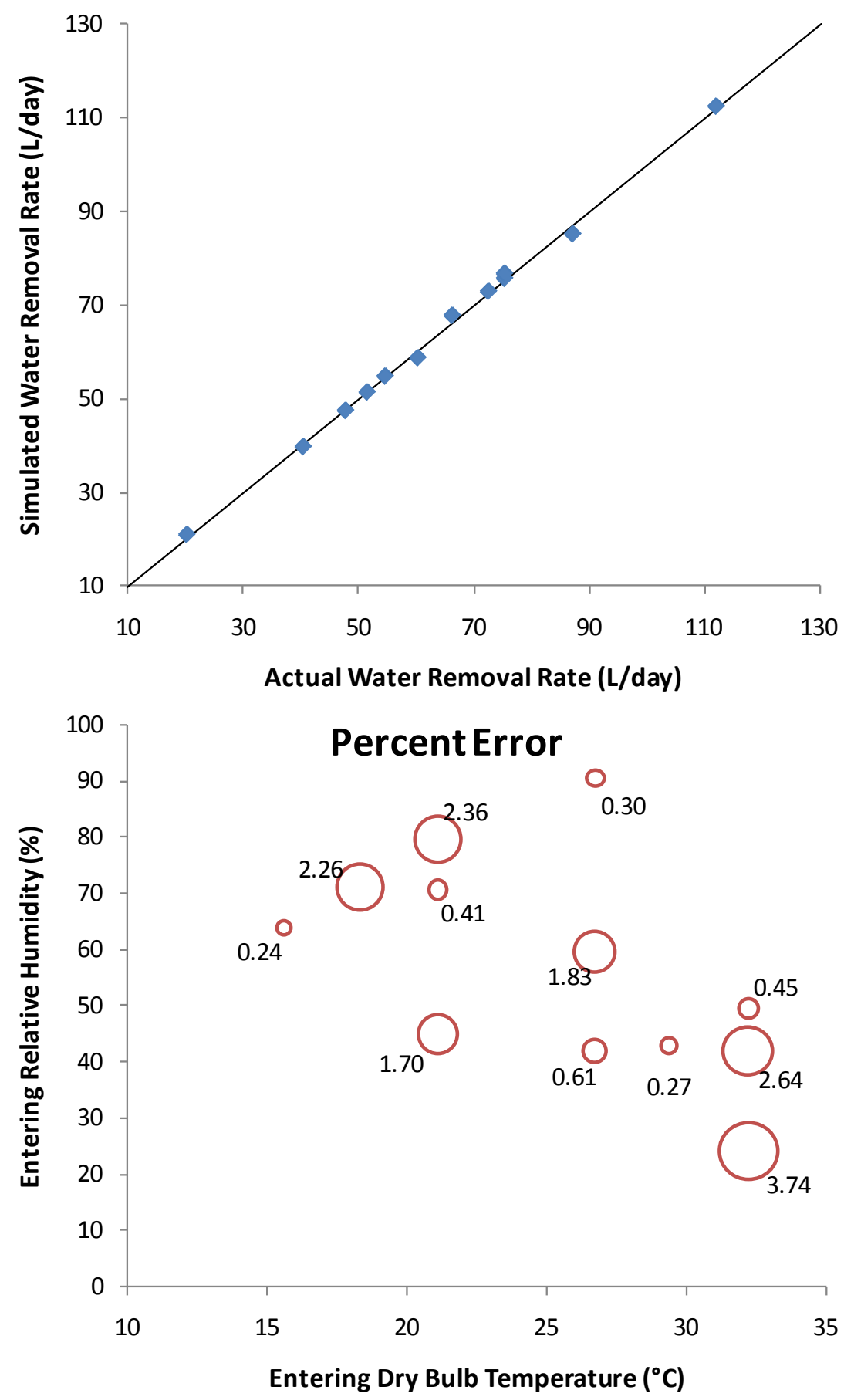

Figure 12. EnergyPlus Model - Water Removal Rate (L/day) 

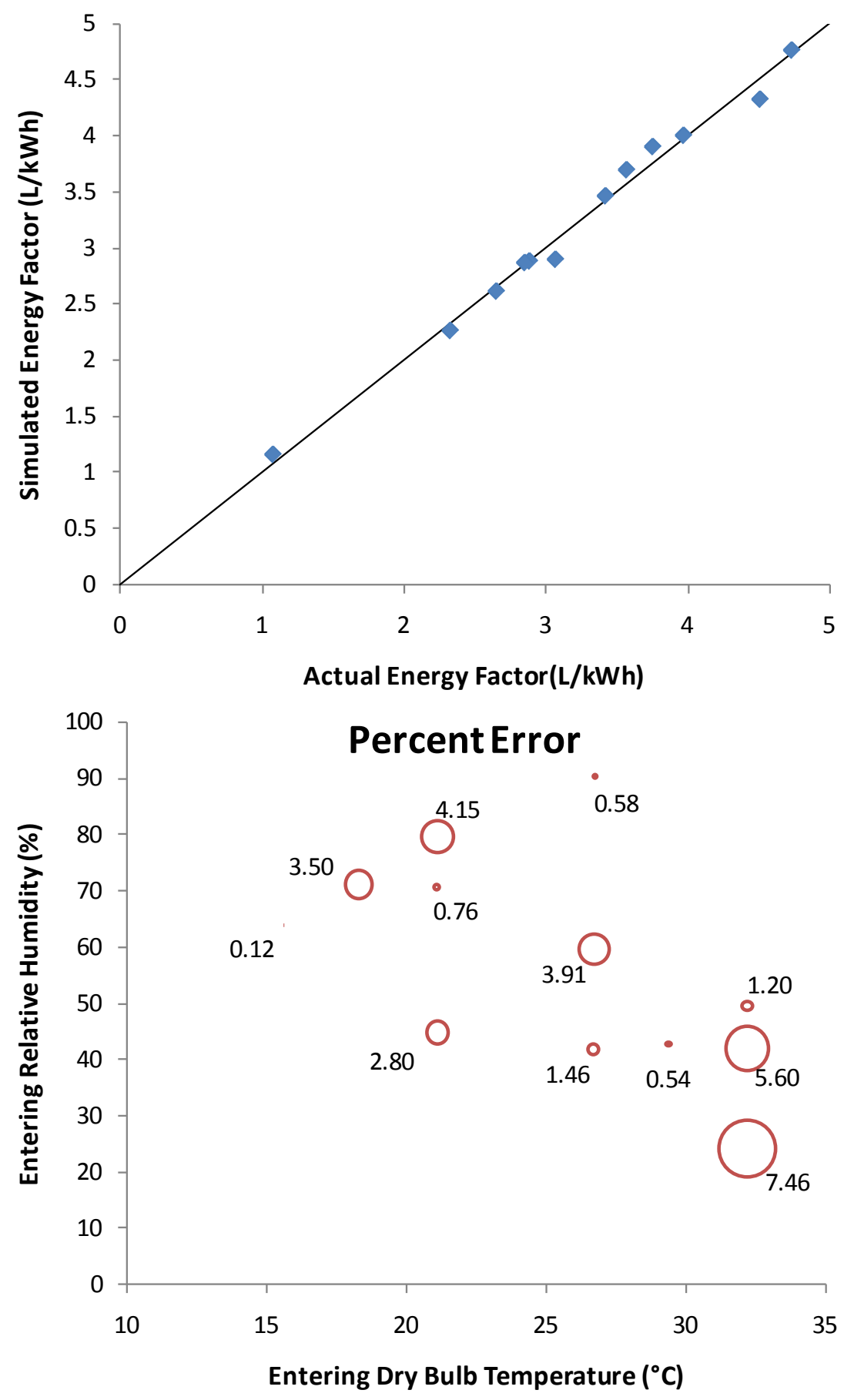

Figure 13. EnergyPlus Model - Energy Factor (L/kWh) 


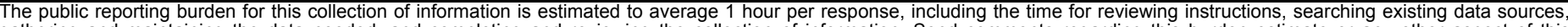

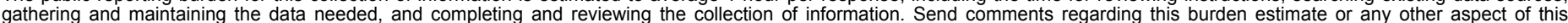

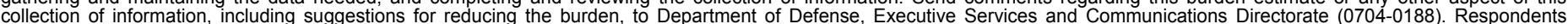

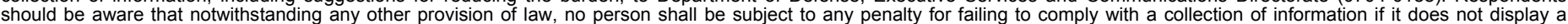

should be aware that notwithstanding

PLEASE DO NOT RETURN YOUR FORM TO THE ABOVE ORGANIZATION.

\begin{tabular}{l|l|l|l} 
1. REPORT DATE $(D D-M M-Y Y Y Y)$ & 2. REPORT TYPE & 3. DATES COVERED (FrOm - TO)
\end{tabular}

December 2009

Technical Report

4. TITLE AND SUBTITLE

Laboratory Test Report for ThermaStor Ultra-Aire XT150H

Dehumidifier 5a. CONTRACT NUMBER

DE-AC36-08-GO28308

5b. GRANT NUMBER

5c. PROGRAM ELEMENT NUMBER

5d. PROJECT NUMBER

NREL/TP-550-47215

5e. TASK NUMBER

BET98001

5f. WORK UNIT NUMBER
7. PERFORMING ORGANIZATION NAME(S) AND ADDRESS(ES)

National Renewable Energy Laboratory

1617 Cole Blvd.

Golden, CO 80401-3393
8. PERFORMING ORGANIZATION REPORT NUMBER

NREL/TP-550-47215

9. SPONSORING/MONITORING AGENCY NAME(S) AND ADDRESS(ES)

10. SPONSOR/MONITOR'S ACRONYM(S)

NREL

11. SPONSORING/MONITORING AGENCY REPORT NUMBER

12. DISTRIBUTION AVAILABILITY STATEMENT

National Technical Information Service

U.S. Department of Commerce

5285 Port Royal Road

Springfield, VA 22161

13. SUPPLEMENTARY NOTES

14. ABSTRACT (Maximum 200 Words)

This report documents the measured performance of the ThermaStor Ultra-Aire XT150H Dehumidifier. The equipment is an ENERGY STAR® vapor-compression cycle whole-house unit. Its performance was measured across a wide range of inlet air conditions and fit to a numerical model with $\mathrm{R}$-squared values greater than 0.998 for electrical power consumption, sensible and latent load removal. The numerical fit was then used to implement the Zone Air Direct-Expansion Dehumidifier performance model in EnergyPlus.

15. SUBJECT TERMS

thermastor; thermastor ultra-aire; ultra-aire; xt150h; dehumidifier

\begin{tabular}{|c|c|c|}
\hline $\begin{array}{l}\text { a. REPORT } \\
\text { Unclassified }\end{array}$ & $\begin{array}{l}\text { b. ABSTRACT } \\
\text { Unclassified }\end{array}$ & $\begin{array}{l}\text { c. THIS PAGE } \\
\text { Unclassified }\end{array}$ \\
\hline
\end{tabular}

\begin{tabular}{l|l|}
$\begin{array}{l}\text { 17. LIMITATION } \\
\text { OF ABSTRACT }\end{array}$ & $\begin{array}{l}\text { 18. } \\
\text { NUMBER } \\
\text { OF PAGES }\end{array}$ \\
UL & \\
\end{tabular}

19a. NAME OF RESPONSIBLE PERSON

19b. TELEPHONE NUMBER (Include area code) 